prof. zw. dr hab. Krystyna Ewa KIETLIŃSKA

Akademia Humanistyczno-Ekonomiczna w Lodzi

e-mail: krystyna.kietlinska@uni.lodz.pl

ORCID: 0000-0001-7691-9900

DOI: $10.15290 /$ oes.2018.03.93.08

\title{
ROLA ŚRODKÓW PUBLICZNYCH W FINANSOWANIU AKTYWNOŚCI ZAWODOWEJ OSÓB NIEPEŁNOSPRAWNYCH W POLSCE
}

\begin{abstract}
Streszczenie
Niepełnosprawni mają swoje miejsce w społeczeństwie. Jednym ze sposobów ich aktywizacji zawodowej jest stworzenie dla nich miejsc pracy. Zatrudnienie osób niepełnosprawnych jest możliwe głównie dzięki tworzeniu przedsiębiorstw społecznych. Ich działalność oferuje różne rodzaje pomocy publicznej. Ta forma pomocy nieustannie zmienia się w naszym kraju. Celem artykułu jest ocena zmian poziomu wydatków publicznych przeznaczonych na aktywizację zawodową osób niepełnosprawnych w Polsce i ich konsekwencje. Zakres badań obejmuje cztery lata (2013-2016).
\end{abstract}

Słowa kluczowe: niepełnosprawni, aktywizacja zawodowa, dochody publiczne, wydatki, bariery

\section{THE ROLE OF PUBLIC MEANS IN FINANCINGO CCUPATION OF DISABLED PERSONS IN POLAND}

\begin{abstract}
Summary
The disabled need to have their place in the society. One of the ways of their professional activation is creating work places for them. Employment of the disabled is possible mainly thanks to the creation of social enterprises. Their activity offers different kinds of public support. This ways of support constantly changes in our country. The paper aims to assess the changes of public expenditure devoted to the professional activation of disabled people in Poland and their consequences. The scope of research concerns four years (2013-2016).
\end{abstract}

Keywords: incomplete, professional activation, public revenues, expenses, barriers

JEL classification: A13, B55

\section{Wstęp}

Liczbę osób niepełnosprawnych w naszym kraju szacuje się na ok. 4,5 mln czyli ponad $12 \%$ ogółu ludności. W życiu codziennym napotykają one na szereg barier. Ich ograniczenie możliwe jest dzięki procesom rehabilitacji: leczniczej, psychologicznej, społecznej i zawodowej. Cały ten proces zmierza do tego, aby osobie nie- 
pełnosprawnej przywrócić zdolność do pracy. Zatrudnienie osób niepełnosprawnych możliwe jest głównie przez tworzenie przedsiębiorstw społecznych, które nie są nastawione na osiaganie zysku lecz na tworzenie miejsc pracy dla tej szczególnej grupy osób. Ich działalność możliwa jest dzięki pomocy publicznej o charakterze finansowym i pozafinansowym.

Celem artykułu jest ocena zmian poziomu wydatków publicznych przeznaczonych na aktywizację zawodową osób niepełnosprawnych w Polsce i ich konsekwencji.

Do środków publicznych zaliczono zarówno środki wszystkich szczebli samorządu terytorialnego, jak i publicznych instytucji powołanych do tego celu. Dysponentem tych środków jest PFRON, którego głównym zadaniem jest przeznaczenie tych środków na rehabilitację społeczną i zawodową oraz zatrudnienie osób niepełnosprawnych.

Zakres badań obejmuje lata 2013-2016. W pracy przyjęto następująca hipotezę badawcza: środki publiczne przeznaczone na aktywizację zawodową osób niepełnosprawnych w niewielkim stopniu przyczyniają się do wzrostu zatrudnienia tej grupy osób.

\section{Pojęcie i rodzaje niepełnosprawności}

Postęp cywilizacyjny przynosi ze sobą niebezpieczeństwo chorób lub kalectwa. Osoby nimi dotknięte powinny mieć szansę sprawnego funkcjonowania w społeczeństwie oraz realizowania się w życiu prywatnym i zawodowym.

W drugiej połowie XX wieku pojęcia choroby i kalectwa zaczęły ewoluować i wyodrębniono z nich takie kategorie jak: ograniczona sprawność, inwalidztwo, niepełnosprawność [Kowalczyk, 1993, s. 12]. Ta ostatnia kategoria będzie przedmiotem dalszych rozważań. Pojęcie niepełnosprawności nie jest łatwe do określenia. Według Banku Światowego osoba niepełnosprawna to jednostka w pełni swoich praw, znajdująca się w sytuacji upośledzającej ją na skutek barier środowiskowych, ekonomicznych i społecznych, których z powodów występujących w niej uszkodzeń nie może przezwyciężyć w taki sposób, jak inni ludzie [Frąckiewicz-Wronka, Zrałek, 2002].

W Polsce obowiazzuje aktualnie definicja osoby niepełnosprawnej zapisana w Karcie Praw Osób Niepełnosprawnych. Za osobę niepełnosprawną uznaje się w niej osobę ,której sprawność fizyczna, psychiczna lub umysłowa trwale lub okresowo utrudnia, ogranicza lub uniemożliwia życie codzienne, naukę, pracę oraz pełnienie ról społecznych zgodnie z normami prawnymi i zwyczajowymi”" [Uchwała Sejmu ..., 1997]. Definicja ta stała się podstawą do określenia kategorii osób niepełnosprawnych zawartą w ustawie o rehabilitacji zawodowej i społecznej oraz zatrudnieniu osób niepełnosprawnych [Ustawa 1997].

W Polsce jest około 5 mln osób niepełnosprawnych, co stanowi około 13\% ludności ogółem [GUS BAEL].

W tej grupie mieszczą się dwie kategorie osób niepełnosprawnych:

- w znaczeniu prawnym, czyli osoby posiadające orzeczenie o niepełnosprawności. Jest ich ok. 4,5 mln i stanowią około $12 \%$ ogółu ludności; 
- $\quad$ w znaczeniu biologicznym, czyli osoby, które uważają się za niepełnosprawne, ale nie posiadaja formalnego orzeczenia. Ich liczba wynosi około $1 \mathrm{mln}$ i stanowią one około $2 \%$ ogółu ludności.

W grupie osób prawnie niepełnosprawnych znajdują się osoby o różnym stopniu niepełnosprawności. Ich odsetek jest następujący:

- o znacznym stopniu niepełnosprawności - 24\%;

- o umiarkowanym stopniu niepełnosprawności - 35\%;

- o nieustalonym stopniu niepełnosprawności - 9\% [Narodowa Strategia ..., 2004].

Mimo wielu form pomocy w podejmowaniu aktywności zawodowej przez osoby niepełnosprawne, ich zatrudnienie w dalszym ciagu pozostawia wiele do życzenia.

Badania Aktywności Ekonomicznej Ludności (BAEL) prowadzone przez GUS pokazują niezbyt optymistyczny obraz dotyczący aktywności zawodowej osób niepełnosprawnych (tabela 1 ).

TABELA 1

Struktura aktywności ekonomicznej osób prawnie niepełnosprawnych w latach 2009-2016 (w tys.)

\begin{tabular}{|l|c|c|c|c|c|c|c|c|c|c|c|c|c|c|c|c|c|}
\hline & \multicolumn{2}{|c|}{2009} & \multicolumn{2}{|c|}{2010} & \multicolumn{2}{|c|}{$\mathbf{2 0 1 1}$} & \multicolumn{2}{c|}{$\mathbf{2 0 1 2}$} & \multicolumn{2}{|c|}{$\mathbf{2 0 1 3}$} & \multicolumn{2}{|c|}{$\mathbf{2 0 1 4}$} & \multicolumn{2}{|c|}{$\mathbf{2 0 1 5}$} & \multicolumn{2}{|c|}{$\mathbf{2 0 1 6}$} \\
\hline $\begin{array}{l}\text { niepełnosprawni } \\
\text { ogółem }\end{array}$ & 3,506 & 100,0 & 3,398 & 100,0 & 3,339 & 100,0 & 3,361 & 100,0 & 3,320 & 100,0 & 3,254 & 100,0 & 3,222 & 100,0 & 3,167 & 100,0 \\
\hline $\begin{array}{l}\text { aktywni } \\
\text { zawodowo } \\
\text { ogółem }\end{array}$ & 552 & 15,7 & 576 & 17,0 & 555 & 16,6 & 585 & 17,4 & 575 & 17,3 & 567 & 17,4 & 536 & 117 & 5512 & 116,1 \\
\hline pracujący & 485 & 13,8 & 493 & 14,5 & 472 & 14,1 & 495 & 14,7 & 478 & 14,4 & 483 & 14,8 & 470 & 114 & 4463 & 114,6 \\
\hline bezrobotni & 67 & 1,9 & 83 & 2,4 & 82 & 0,1 & 91 & 2,7 & 97 & 2,9 & 83 & 2,6 & 666 & 02,0 & 448 & 11,5 \\
\hline
\end{tabular}

Źródło: opracowanie własne na podstawie [GUS BAEL].

Z danych zawartych w tabeli 1 wynika, że liczba zarejestrowanych osób niepełnosprawnych w badanym okresie maleje z 3,506 tys. do 3,167 tys. w 2016 r.

Trudno ocenić, co jest powodem tej zmiany. Jednym z nich może być zwiększenie rygorów dotyczących uzyskania statusu osoby niepełnosprawnej. Liczba osób aktywnych zawodowo ulega wahaniom, co może wynikać ze zmiany form pomocy dla przedsiębiorstw zatrudniajacych osoby niepełnosprawne. Jest to bardzo pesymistyczny obraz, jeśli weźmie się pod uwagę fakt, że aktywne zawodowo osoby stanowią jedynie około 15-17\% osób niepełnosprawnych. Oznacza to, że około 85\% tej grupy społecznej jest bierna zawodowo. Ich źródła utrzymania obrazuje tabela 2.

Obraz osób niepełnosprawnych przedstawiony w tabelach 1 i 2 wskazuje, że sytuacja w jakiej się one znajduja jest bardzo trudna. Z punktu widzenia osób niepełnosprawnych powoduje ona dyskomfort społeczny i psychiczny tej grupy społecznej. Dla gospodarki jest to natomiast znaczne obciążenie ekonomiczne. Dlatego konieczne jest podejmowanie działań zmierzających do zwiększenia aktywności zawodowej osób niepełnosprawnych. Dzięki temu będą one miały szansę stać się pełno- 
wartościowymi i samodzielnymi obywatelami, a państwo nie będzie ponosić kosztów ich utrzymania. Jednak zatrudnienie osób niepełnosprawnych wiąże się z ponoszeniem przez pracodawców dodatkowych obowiązków i obciążeń. Aby przedsiębiorca mógł im sprostać, musi uzyskać wsparcie od państwa, samorządów lokalnych, funduszy lub organizacji pozarządowych.

TABELA 2

Odsetek biernych zawodowo osób niepełnosprawnych w wieku produkcyjnym według głównego źródła utrzymania

\begin{tabular}{|l|c|}
\hline ogółem & 100 \\
\hline emerytura & 5,7 \\
\hline renta z tytułu niezdolności do pracy & 80,4 \\
\hline renta socjalna & 4,8 \\
\hline renta rodzinna & 1,6 \\
\hline zasiłki & 1,3 \\
\hline utrzymani przez rodzinę & 3,1 \\
\hline inne & 3,1 \\
\hline
\end{tabular}

Źródło: [Raport „Rynek pracy OZ 2005”].

\section{Formy zatrudnienia osób niepełnosprawnych}

Wśród form aktywizacji zawodowej osób niepełnosprawnych wyróżniamy:

- $\quad$ zatrudnienie w Zakładach Aktywności Zawodowej (ZAZ);

- zatrudnienie w Zakładach Pracy Chronionej (ZPCh);

- $\quad$ zatrudnienie w spółdzielni socjalnej;

- samozatrudnienie;

ZAZ i ZPCh tworzą chroniony rynek pracy co oznacza, że powoływane sa głównie dla osób niepełnosprawnych i są dostosowane do ich psychofizycznych możliwości i ograniczonej zdolności pracy [Przybyłka, 2001, s. 44].

Zakłady Aktywizacji Zawodowej powoływane sa przez powiaty, gminy, fundacje, stowarzyszenia lub inne organizacje społeczne, których statutowym zadaniem jest rehabilitacja społeczna i zawodowa osób niepełnosprawnych [Frąckiewicz-Wronka, Zrałek, 2002, s. 197].

ZAZ zatrudniają osoby posiadające głównie znaczny stopień niepełnosprawności. Aby uzyskać ten status muszą zatrudniać 70\% osób niepełnosprawnych. Ich zadaniem jest przygotowanie do samodzielnego aktywnego życia przez rehabilitację społeczną i zawodową oraz zapewnienie pracy odpowiedniej do możliwości psychofizycznych niepełnosprawnego za stosowne wynagrodzenie.

ZAZ musi ponadto zapewniać specjalistyczna, doraźną opiekę medyczną, usługi rehabilitacyjne oraz dostosować obiekty i pomieszczenia użytkowe do możliwości i potrzeb niepełnosprawnych pracowników, przy uwzględnieniu zasad BHP. 
Głównym pracodawcą osób niepełnosprawnych o każdym stopniu niepełnosprawności są Zakłady Pracy Chronionej (ZPCh). Są to przedsiębiorstwa rynkowe, którym status nadaje wojewoda, opierając się na wniosku oraz ustawowo wymaganych warunkach specjalnych przez pracodawcę [Ustawa 1997] Do warunków jakie musi spełnić pracodawca należą:

- prowadzenie działalności przez co najmniej 12 miesięcy;

- zatrudnienie nie mniej niż 25 pracowników w pełnym wymiarze czasu pracy;

- zatrudnienie określonego odsetka osób niepełnosprawnych, w tym osób o znacznym lub umiarkowanym stopniu niepełnosprawności;

- $\quad$ przystosowanie obiektów i pomieszczeń ZPCh do potrzeb osób niepełnosprawnych;

- $\quad$ organizowanie szkoleń dla osób niepełnosprawnych;

- prowadzenie poradnictwa zawodowego;

- zapewnienie doraźnej specjalistycznej opieki medycznej, poradnictwa i rehabilitacji;

- posiadanie pozytywnej opinii Państwowej Inspekcji Pracy.

Wymienione zadania ciążące na pracodawcy są trudne do zrealizowania przede wszystkim dlatego, że ZPCh podlegają prawom gospodarki rynkowej. Tak jak przedsiębiorstwa klasyczne muszą one walczyć o pozycję rynkową, klientów, rynki zbytu oraz środki na dalsze funkcjonowanie [Barczyński, 2010, s. 17].

Miejsca pracy dla osób niepełnosprawnych tworzone są także w formie spółdzielni socjalnych, podmiotów działających na otwartym rynku pracy lub samozatrudnienia. Spółdzielnia socjalna to stosunkowo nowy podmiot w polskim systemie prawnym [Ustawa 2006]. Jej zadaniem jest reintegracja społeczna i zawodowa oraz tworzenie miejsc pracy dla osób wykluczonych społecznie, do których zalicza się także osoby niepełnosprawne o umiarkowanym i znacznym stopniu niepełnosprawności. Prowadzą one dwa rodzaje działalności:

- działalność gospodarcza, realizowaną na zasadach rynkowych;

- aktywność w zakresie reintegracji społecznej i zawodowej oraz działalność społecznie użyteczną [Kietlińska, 2010, s. 61-168].

Zatrudnienie osób niepełnosprawnych na otwartym rynku pracy może przyjać trzy formy:

- $\quad$ zatrudnienia na takich samych stanowiskach jak pracownicy pełnosprawni;

- zatrudnienia na stanowiskach specjalnie dobranych i przystosowanych do psychofizycznych możliwości osób niepełnosprawnych [Poliwczak, 2007, s. 148].

- zatrudnienia wspieranego, które kierowane jest do osób o umiarkowanym i znacznym stopniu niepełnosprawności. Polega ono na tym, że oprócz osoby niepełnosprawnej zatrudnia się dodatkowo osobę pełnosprawną (trenera pracy, asystenta zawodowego), która ma wspomagać ją w trakcie wykonywanej pracy tak długo, jak to jest konieczne [Majewski, 2005, s. 14-16]. 
Oprócz zatrudnienia w zwykłych zakładach pracy, obszarem aktywności zawodowej osób niepełnosprawnych może być założenie własnej firmy bądź samozatrudnienie [Szymanowska, 2003, s. 7].

Zakłady pracy chronionej oraz instytucje rynkowe realizuja tylko zadania ekonomiczne ale i społeczne, bowiem celem ich działania nie jest osiaganie zysku lecz tworzenie miejsc pracy dla osób niepełnosprawnych. Z tego względu ich funkcjonowanie na rynku nie byłoby możliwe bez pomocy państwa, samorząóo terytorialnych, funduszy oraz organizacji pozarządowych. Jednym z głównych źródeł pomocy dla przedstawionych instytucji (z wyjątkiem spółdzielni socjalnych) są środki Państwowego Funduszu Rehabilitacji Osób Niepełnosprawnych (PFRON).

\section{Działania instytucji publicznych na rzecz zatrudnienia osób niepełnosprawnych}

\subsection{Rola PFRON w finansowaniu aktywności zawodowej osób niepełnosprawnych}

Jedynym podmiotem, który gromadzi środki przeznaczone na rehabilitację społeczną i zawodową oraz zatrudnienie osób niepełnosprawnych jest Państwowy Fundusz Rehabilitacji Osób Niepełnosprawnych.

Utworzony na mocy ustawy z 9.05.1991 r. o zatrudnieniu i rehabilitacji zawodowej osób niepełnosprawnych [Ustawa 1991]. Obecnie działa na podstawie ustawy z 27.08.1997 r. o rehabilitacji zawodowej i społecznej oraz zatrudnieniu osób niepełnosprawnych [Ustawa 1997]. PFRON posiada osobowość prawną. Nadzór nad jego funkcjonowaniem sprawuje minister właściwy do spraw zabezpieczenia społecznego [Malinowska-Misiag, Misiag, 2006, s. 233]. Podstawowymi jednostkami organizacyjnymi PFRON sa: Biuro Funduszu z siedzibą w Warszawie oraz 16 oddziałów terenowych w każdym województwie. Zadania PFRON realizowane są trzema drogami:

- przez działania własne;

- $\quad$ w drodze zlecenia zadań samorządom wojewódzkim i powiatowym;

- przez zlecenie zadań innym podmiotom na podstawie zawartych umów [Mączyński, 2002, s. 36].

Do zadań własnych realizowanych przez PFRON należa:

- $\quad$ wyrównywanie różnic między regionami w szczególności w jednostkach samorządu terytorialnego, w których stopa bezrobocia jest wyższa niż $110 \%$ średniej stopy bezrobocia w kraju lub w których brak jest warsztatu terapii zajęciowej albo zakładu aktywności zawodowej;

- realizacja programów wspieranych ze środków UE na rzecz osób niepełnosprawnych;

- dofinansowanie zadań wynikających z programów rządowych, w tym dotyczących rozwoju zasobów ludzkich oraz przeciwdziałania wykluczeniu społecznemu osób niepełnosprawnych, a także pomoc rodzinom, których członkami są osoby niepełnosprawne; 
- realizacja programów służących rehabilitacji społecznej i zawodowej, adresowanych głównie do osób niepełnosprawnych i ich rodzin;

- finansowanie w części lub w całości ekspertyz i analiz dotyczących rehabilitacji społecznej i zawodowej [Kuźnicki, Krupa, 2000, s. 80-93].

- dofinansowanie wynagrodzeń pracowników niepełnosprawnych oraz ich składek na ubezpieczenie społeczne.

Zadaniom realizowanym przez PFRON przypisane są określone źródeł finansowania. Można je podzielić na kilka grup:

- Środki własne, do których należą:

- dochody z działalności gospodarczej;

- dywidendy;

- dochody z oprocentowania pożyczek, lokat, dyskonto od zakupionych bonów skarbowych, odsetki od obligacji skarbowych itp.;

- wpłaty pracodawców:

- obowiązkowe - z tytułu zatrudnienia określonej przepisami liczby zatrudnionych;

- zwrot kwot otrzymanych z PFRON w związku z zatrudnieniem osób niepełnosprawnych na okres krótszy niż przewidują przepisy;

- o charakterze sanacyjnym, którzy otrzymali środki na podjęcie działalności gospodarczej, rolniczej lub na wkład do spółdzielni socjalnej, jeśli z przyczyn leżących po ich stronie zostały naruszone warunki umowy [Mączyński, 2002, s. 33-34].

- środki budżetu państwa w postaci dotacji celowych;

- spadki, darowizny, zapisy;

- dobrowolne wpłaty pracodawców.

Czasowo wolne środki PFRON może lokować w bonach skarbowych, obligacjach skarbowych, lokatach terminowych w NBP lub BGK.

\subsection{Rodzaje zadań zlecanych przez PFRON samorządom wojewódzkim i powiatowym}

Część zadań dotyczących osób niepełnosprawnych jest zgodnie z ustawą [Ustawa 1997] zlecana samorządom wojewódzkim i powiatowym. PFRON jest zobowiązany do zwrotu kosztów lub dofinansowania kosztów zleconych zadań. Dofinansowanie zadań zleconych samorządom wojewódzkim dotyczy:

- zwrotu kosztów szkolenia zatrudnienia osób niepełnosprawnych związanych ze zmiana profilu produkcji;

- jednorazowej pożyczki w celu ochrony istniejących w zakładzie miejsc pracy osób niepełnosprawnych;

- dofinansowania robót budowlanych dotyczących obiektów służących rehabilitacji osób niepełnosprawnych;

- dofinansowania kosztów tworzenia i działania zakładów aktywności zawodowej;

- pokrywania kosztów utworzenia, działalności oraz realizacji zadań specjalistycznego ośrodka. 
Samorządy powiatowe otrzymuja z PFRON środki przeznaczone na następujące zadania:

- dofinansowanie kosztów tworzenia i działalności warsztatów terapii zajęciowej;

- częściowe dofinansowanie turnusów rehabilitacyjnych dla osób niepełnosprawnych i ich opiekunów;

- dofinansowanie zaopatrzenia w sprzęt rehabilitacyjny, przedmioty ortopedyczne i środki pomocnicze;

- pomoc finansowa przy likwidacji barier architektonicznych, technicznych, sposobach komunikacji związanych $\mathrm{z}$ indywidualnymi potrzebami osób niepełnosprawnych;

- dofinansowanie rehabilitacji dzieci i młodzieży;

- dofinansowanie rozwoju sportu, kultury, turystyki i rekreacji dla osób niepełnosprawnych;

- $\quad$ zwrot kosztów przystosowania tworzonych lub istniejących stanowisk pracy dla osób niepełnosprawnych, dostosowanych do potrzeb wynikających $z$ ich niepełnosprawności;

- pośrednictwo pracy, pośrednictwo zawodowe, szkolenia oraz przekwalifikowania osób niepełnosprawnych. Dotyczy to m.in. pożyczek dla osób niepełnosprawnych na podjęcie działalności gospodarczej, rolniczej, lub wniesienia wkładu do spółdzielni socjalnej [Zatrudnienie osób niepetnosprawnych ..., 2008, s. 28].

\section{5. Źródła przychodów i kierunki wydatkowania środków PFRON}

\subsection{Przychody PFRON i ich rodzaje}

Na przychody PFRON składają się:

- $\quad$ dotacje z budżetu państwa, które ustawowo przeznaczone są na następujące cele:

- zrekompensowanie gminom 50\% dochodów utraconych z tytułu ustawowych zwolnień podmiotów zatrudniających osoby niepełnosprawne z podatku: od nieruchomości, rolnego, leśnego, i od czynności cywilnoprawnych;

- dofinansowania wynagrodzeń pracowników niepełnosprawnych;

- środki UE;

- wpłaty zakładów pracy, do których zobligowane są przedsiębiorstwa zatrudniające co najmniej 25 pracowników w przeliczeniu na pełny wymiar czasu pracy:

- jednostki i zakłady budżetowe oraz instytucje kultury, uczelnie, szkoły zawodowe, placówki opiekuńczo-wychowawcze i resocjalizacyjne, które na mocy odrębnych przepisów moga deklarować określone środki pieniężne; 
- przelewy redystrybucyjne, czyli środki niewykorzystane przez samorządy w poprzednim roku;

- pozostałe przychody, do których m.in. zalicza się wpływy z tytułu grzywien i kar pieniężnych, ze sprzedaży, najmu lub dzierżawy składników majątku, odsetek i zwrotów z różnych tytułów.

Strukturę przychodów PFRON w latach 2013-2016 przedstawia tabela 3.

TABELA 3

Struktura przychodów PFRON w latach 2013-2016

\begin{tabular}{|l|c|c|c|c|c|c|c|c|}
\hline \multirow{2}{*}{ wyszczególnienie } & \multicolumn{2}{|c|}{$\mathbf{2 0 1 3}$} & \multicolumn{2}{c|}{2014} & \multicolumn{2}{c|}{2015} & \multicolumn{2}{c|}{2016} \\
\cline { 2 - 9 } & $\mathbf{m l n} \mathbf{z ł}$ & $\mathbf{0}$ & $\mathbf{m l n} \mathbf{z ł}$ & $\mathbf{\%}$ & $\mathbf{m l n} \mathbf{z}$ & $\mathbf{\%}$ & $\mathbf{m l n} \mathbf{z ł}$ & $\mathbf{\%}$ \\
\hline ogółem & 4617,8 & 100 & 4668,8 & 100 & 4676,6 & 100 & 4704,9 & 100 \\
\hline dotacje z budżetu & 745,4 & 16,1 & 745,4 & 16 & 741,5 & 15,9 & 742,4 & 15,8 \\
\hline środki z UE & 35,6 & 0,8 & 59,5 & 1,3 & 47,9 & 1,02 & 0,2 & 0,004 \\
\hline $\begin{array}{l}\text { wpłaty z zakładów } \\
\text { pracy }\end{array}$ & 3632,8 & 78,6 & 3651,9 & 78,2 & 3620,9 & 77,4 & 3742,2 & 79,5 \\
\hline zwroty & 7,4 & 0,2 & 1,4 & 0,02 & 2,1 & 0,04 & 1,6 & 0,03 \\
\hline pozostałe & 196,6 & 4,3 & 210,7 & 4,5 & 5,64 & 5,64 & 218,6 & 4,6 \\
\hline
\end{tabular}

Źródło: Opracowanie własne na podstawie [PFRON, Sprawozdanie za lata 2013-2016].

Z danych zawartych w tabeli 3 wynika, że głównym źródłem przychodów PFRON są wpłaty zakładów pracy zatrudniających co najmniej 25 osób niepełnosprawnych. Są one zobowiązane do comiesięcznej zapłaty na Fundusz kwoty stanowiącej iloczyn 40,65\% przeciętnego wynagrodzenia i liczby pracowników, odpowiadający różnicy między wskaźnikiem zatrudnienia osób niepełnosprawnych (6\%), a faktycznym zatrudnieniem. Stanowią one niemal 80\% wszystkich dochodów PFRON.

Drugim co do wielkości źródłem zasilania PFRON są środki z budżetu państwa, które stanowią około 16\% ogółu dochodów Funduszu. Jednak na pomoc osobom niepełnosprawnym przeznacza się z tego źródła tylko część środków. Reszta przekazywana jest gminom z tytułu utraconych dochodów z podatków, od płacenia których zwolnieni są pracodawcy osób niepełnosprawnych. Pozostałe przychody odgrywają niewielką rolę w zasilaniu PFRON. Niepokojący jest niewielki udział środków UE w dochodach Funduszu. 


\subsection{Kierunki wydatkowania środków PFRON}

Środki, które gromadzi PFRON przeznaczone są na następujące cele:

- dotacje na działalność bieżąca podmiotów zatrudniających osoby niepełnosprawne zarówno o statusie podmiotów publicznych jak i niepublicznych;

- dotacje na inwestycje wymienionych podmiotów;

- przelewy redystrybucyjne, które przekazywane są samorządom wojewódzkim i powiatowym na realizacje zadań dotyczących zatrudnienia i rehabilitacji osób niepełnosprawnych;

- $\quad$ transfery pieniężne lub w postaci pomocy rzeczowej na rzecz indywidualnych osób niepełnosprawnych;

- $\quad$ wydatki na własną działalność bieżącą $\mathrm{i}$ inwestycyjna;

- $\quad$ wydatki na dofinansowanie programów realizowanych ze środków UE.

Strukturę wydatków PFRON w latach 2013-2016 obrazuje tabela 4.

TABELA 4

Struktura wydatków PFRON w latach 2013-2016

\begin{tabular}{|c|c|c|c|c|c|c|c|c|}
\hline \multirow{2}{*}{ wyszczególnienie } & \multicolumn{2}{|c|}{2013} & \multicolumn{2}{|c|}{2014} & \multicolumn{2}{|c|}{2015} & \multicolumn{2}{|c|}{2016} \\
\hline & $\operatorname{mln} \mathrm{z} 1$ & $\%$ & $\mathrm{mln} z 1$ & $\%$ & $\operatorname{mln} z 1$ & $\%$ & $\mathrm{mln} \mathrm{zX}$ & $\%$ \\
\hline ogółem & 4871,7 & 100 & 4760,3 & 100 & 4600,2 & 100 & 4720,3 & 100 \\
\hline \multicolumn{9}{|l|}{ dotacje na: } \\
\hline zadania bieżące & 3604,7 & 74 & 3405 & 71,5 & 3317,5 & 72,1 & 3393,5 & 72 \\
\hline inwestycje & 130,7 & 2,7 & 120,1 & 2,5 & 19,3 & 0,4 & 99,4 & 2,1 \\
\hline $\begin{array}{l}\text { przelewy redystry- } \\
\text { bucyjne }\end{array}$ & 798,4 & 16,4 & 878,7 & 18,5 & 913,8 & 19,9 & 920,4 & 19,5 \\
\hline $\begin{array}{l}\text { zwrot źle wykorzy- } \\
\text { stanych dotacji }\end{array}$ & 0,5 & 0,01 & 0,2 & 0,004 & 2,6 & 0,1 & 0,3 & 0,01 \\
\hline $\begin{array}{l}\text { transfery na rzecz } \\
\text { ludności }\end{array}$ & 3,9 & 0,08 & 4,3 & 0,1 & 5,0 & 0,1 & 5,9 & 0,1 \\
\hline $\begin{array}{l}\text { wydatki własne } \\
\text { bieżące }\end{array}$ & 275,6 & 5,7 & 284,3 & 6,0 & 300,4 & 6,5 & 293,7 & 6,2 \\
\hline $\begin{array}{l}\text { wydatki własne } \\
\text { inwestycyjne }\end{array}$ & 11,8 & 0,2 & 9,9 & 0,2 & 23,6 & 0,5 & 6,6 & 0,1 \\
\hline $\begin{array}{l}\text { wydatki na pro- } \\
\text { gramy UE }\end{array}$ & 46,1 & 0,9 & 57,8 & 1,2 & 18 & 0,4 & 0,2 & 0,004 \\
\hline
\end{tabular}

Źródło: Opracowanie własne na podstawie [PFRON, Sprawozdanie za lata 2013-2016].

Dane w tabeli 4 wskazuja, że głównym kierunkiem wydatków Funduszu są środki przekazywane na działalność bieżąca podmiotów, które zatrudniają osoby niepełnosprawne (około 70\% ogółu środków). Jest to pozytywne zjawisko, jako że są to głównie pracodawcy osób niepełnosprawnych. 
Nieco mniej pozytywnie można ocenić wysokość środków (około 20\%) przekazywanych na rzecz samorządów wojewódzkiego i powiatowego, które przeznacza się na zatrudnienie i rehabilitację osób niepełnosprawnych.

Niestety niewielki jest udział środków na rzecz osób niepełnosprawnych, które nie pracują (ok. 5-6\% ogółu środków). Są to często osoby, należące do I grupy niepełnosprawności, które nie mogą pracować albo nie mogą znaleźć odpowiedniej pracy. Bardzo niski udział wydatków na dopłaty do programów unijnych wynika z małego udziału tych środków w dochodach PFRON.

\subsection{Stopień pokrycia wydatków PFRON przychodami}

Środki pieniężne zgromadzone przez PFRON służą do realizacji zadań, do których Fundusz został powołany. Ich ilość nie zawsze wystarcza na pokrycie ponoszonych wydatków (por. tabela 5).

\section{Stopień pokrycia wydatków dochodami PFRON}

TABELA 5

\begin{tabular}{|l|c|c|c|c|}
\hline \multicolumn{1}{|c|}{ wyszczególnienie } & $\mathbf{2 0 1 3}$ & $\mathbf{2 0 1 4}$ & $\mathbf{2 0 1 5}$ & $\mathbf{2 0 1 6}$ \\
\hline przychody w mln zł & 4617,8 & 4668,8 & 4676,6 & 4704,9 \\
\hline wydatki w mln. zł & 4871,7 & 4760,3 & 4600,2 & 4720,3 \\
\hline stopień pokrycia w \% & 94,8 & 98,1 & 101,7 & 99,7 \\
\hline
\end{tabular}

Źródło: obliczenia własne.

W badanym okresie jedynie w 2015 roku obserwujemy niewielką nadwyżkę przychodów nad wydatkami. Jedną z przyczyn było znaczne zmniejszenie wydatków na inwestycje w stosunku do pozostałych lat (0,4\% w stosunku do 2,5-2,7\% ogółu środków).

W latach 2013-2014 i 2016 Fundusz miał niewielki deficyt. Największy był w roku 2013. Jedną z przyczyn mogły być znacznie większe niż w pozostałych latach dotacje dla przedsiębiorstw zatrudniających osoby niepełnosprawne (por. tabela 4). W latach 2014 i 2016 niedobór środków był niewielki.

\section{Bariery ograniczające aktywność zawodową osób niepełnosprawnych}

\subsection{Rodzaje barier}

Z przeprowadzonych analiz wynika, że w badanym okresie odsetek osób niepełnosprawnych aktywnych zawodowo utrzymuje się na tym samym poziomie (około 17\%) z czego pracujących jest około 14,5\% a bezrobotnych około 2,5\%.

Odpowiednikiem tego stanu rzeczy są utrzymujące się na niezmienionym poziomie dochody i wydatki Państwowego Funduszu Rehabilitacji Osób Niepełnosprawnych, z którego dofinansowane są zadania w zakresie zatrudnienia osób nie- 
pełnosprawnych. Taka sytuacja jest nieprawidłowa, jeśli weźmie się pod uwagę zakres zjawiska niepełnosprawności.

Jakie są zatem bariery, które powodują, że tak mały odsetek osób niepełnosprawnych jest aktywny zawodowo i nie zmienia się w długim okresie? Jest to kwestia często podnoszona w literaturze, ale ciagle niezbadana [Barczyński, 2010].

W badaniu przeprowadzonym w latach 2006-2007 przez Krajową Izbę Gospodarczo-Rehabilitacyjną, które objęło pracodawców zatrudniających jak i niezatrudniających osoby niepełnosprawne oraz przedstawicieli administracji lokalnej wskazano na 40 potencjalnych barier ujętych w cztery grupy ${ }^{1}$ :

1. bariery wynikające $z$ warunków otoczenia takie m.in., jak: skomplikowane zapisy regulacji prawnych, złożone procedury wsparcia finansowego, niski poziom pośrednictwa pracy, bariery transportowe utrudniające osobom niepełnosprawnym dojazd do pracy;

2. bariery wynikające z postaw pracodawców, do których zaliczono m.in. nieznajomość regulacji prawnych, brak wiedzy o możliwym wsparciu finansowym zatrudnionych osób niepełnosprawnych, obawa przed dodatkowymi kosztami i obowiązkami, niska jakością pracy tych osób;

3. bariery wynikające $z$ warunków środowiska pracy takie jak: konieczność zmian techniczno-organizacyjnych $\mathrm{w}$ firmie, wymagania dotyczące przygotowania obiektów i przystosowania stanowisk pracy, wymagania dotyczące opieki medycznej;

4. bariery wynikające z postaw i cech osób niepełnosprawnych jak np. przeciwwskazania ze względu na stan zdrowia, większa zachorowalność, niskie przygotowanie zawodowe, a zatem niższa wydajność pracy, potrzeba stałej opieki medycznej, konflikt przychodów (praca czy renta).

Mimo iz badanie zostało przeprowadzone ponad 10 lat temu, bariery na które ono wskazuje są nadal aktualne.

\subsection{Zmiany regulacji prawnych dotyczących zatrudnienia osób niepełnosprawnych}

Szeroko zakrojone zmiany w zakresie przywilejów dla podmiotów chronionych są wprowadzone sukcesywnie od 2011 r. Na podstawie Ustawy z 2011 r. wraz z późniejszymi zmianami [Ustawa 1997] zmieniają się niemal wszystkie formy pomocy dla podmiotów zatrudniających osoby niepełnosprawne. Są one następujące:

- wskaźnik zatrudnienia osób niepełnosprawnych został zwiększony z 40\% do $50 \%$ ogółu zatrudnionych, w tym osoby o znacznym i umiarkowanym stopniu niepełnosprawności powinny stanowić co najmniej 20\%, a nie jak dotychczasowo 10\% ogółu zatrudnionych;

\footnotetext{
1 Badanie znaczenia barier informacyjnych dla zwiększenia możliwości zatrudnienia osób niepełnosprawnych - projekt badawczy KJG-R w ramach 1.4 Sektorowego Programu Rozwoju Zasobów Ludzkich 2004-2006 współfinansowany z Europejskiego Funduszu Społecznego [Barczyński, 2010, s. 28-36].
} 
- $\quad$ katalog schorzeń specjalnych (chorzy psychicznie, epileptycy, osoby niewidome) został poszerzony o autyzm. Wówczas dofinansowanie do wynagrodzeń może być podwyższone o $40 \%$;

- czas pracy osób o znacznym i umiarkowanym stopniu niepełnosprawności został zrównany z obowiązującym osoby pełnosprawne, czyli 8 godzin dziennie i 40 godzin tygodniowo;

- $\quad$ ulgi i zwolnienia podatkowe w zasadzie nie uległy zmianie i dotycza:

- ulgi w PIT;

- zwolnienia z podatków: od spadków i darowizn, od czynności cywilnoprawnych, rolnego, leśnego;

- zwolnienia z podatku od nieruchomości, w którym wprowadzono warunek zatrudniania co najmniej 30\% osób niewidomych, psychicznie chorych i upośledzonych umysłowo.

Jednak z punktu widzenia dostępności oraz znaczenia wsparcia finansowego jakiego maja prawo oczekiwać pracodawcy, najistotniejsze jest finansowanie składek na ubezpieczenie społeczne oraz dofinansowanie wynagrodzeń [Ustawa 1997; Rozporządzenie Ministra Pracy i Polityki Społecznej].

Od 2011 r. składki na ubezpieczenie społeczne sa refundowane jedynie osobie niepełnosprawnej wykonującej działalność gospodarczą oraz niepełnosprawnemu rolnikowi lub jego niepełnosprawnemu domownikowi, a nie jak poprzednio pracodawcy.

Kwestie dofinansowania wynagrodzeń reguluje ustawa o rehabilitacji zawodowej oraz Rozporządzenie Ministra Pracy i Polityki Społecznej [Ustawa 1997; Rozporządzenie Ministra Pracy i Polityki Społecznej].

Miesięczne dofinansowanie do wynagrodzeń osób niepełnosprawnych ustalono w procencie do najniższego wynagrodzenia w gospodarce i uzależniono od stopnia niepełnosprawności. Wyniosło ono w 2011 r.:

- $\quad 160 \%$ dla osób o znacznym stopniu niepełnosprawności;

- $\quad 140 \%$ dla osób o umiarkowanym stopniu niepełnosprawności;

- $\quad 60 \%$ dla osób o lekkim stopniu niepełnosprawności;

Od stycznia 2012 r. dopłata wynosi:

- $\quad 180 \%$ dla osób o znacznym stopniu niepełnosprawności;

- $\quad 100 \%$ dla osób o umiarkowanym stopniu niepełnosprawności;

- $\quad 40 \%$ dla osób o lekkim stopniu niepełnosprawności.

Zmiany regulacji prawnych jakie następowały od roku $2011 \mathrm{w}$ odniesieniu do podmiotów zatrudniających osoby niepełnosprawne mają na celu uszczelnienie systemu oraz zmobilizowanie przedsiębiorstw do zatrudnienia osób o znacznym i umiarkowanym stopniu niepełnosprawności na niekorzyść tych o lekkim stopniu niepełnosprawności. Czy jednak zmiany te nie wpływaja na stagnację w zatrudnieniu osób niepełnosprawnych, o czym świadczy utrzymujący się przez wiele lat na tym samym poziomie odsetek osób aktywnych zawodowo? 


\section{Podsumowanie}

Niepełnosprawność jest współcześnie zjawiskiem dość powszechnym. Dlatego podejmowane są działania zmierzające do uaktywnienia zawodowego i społecznego tych osób. Jednak z przeprowadzonych analiz wynika, że jedynie $17 \%$ z nich jest aktywnych zawodowo a ok. $14-15 \%$ pracuje.

Formy aktywności zawodowej osób niepełnosprawnych moga być różne.: od zatrudnienia w Zakładach Aktywności Zawodowej czy Zakładach pracy Chronionej po założenie spółdzielni socjalnej lub samozatrudnienie.

W Polsce przyjęto założenie o niedoskonałości rynku pracy w związku z czym uznaje się zasadę pokrywania ze środków publicznych dodatkowych kosztów utworzenia miejsca pracy przystosowanego dla osoby niepełnosprawnej [Jaworski, 2009, s. 200].

Środki za pomoca których zachęca się pracodawców do zatrudnienia osób niepełnosprawnych pochodzą z różnych źródeł, takich jak: budżet państwa, podmioty gospodarcze, czy środki Unii Europejskiej. Jednak głównym źródłem zasilania są środki przedsiębiorstw. Są one gromadzone na Państwowym Funduszu Rehabilitacji Osób Niepełnosprawnych (PFRON). Analiza przychodów i wydatków tego Funduszu w okresie 4 badanych lat (2013-2016) pozwala na stwierdzenie, że zarówno przychody jak i wydatki utrzymują się ciagle na tym samym poziomie.

Taka sytuacja może oznaczać, że podejmowane przez Fundusz działania nie mobilizują osób niepełnosprawnych do podejmowania pracy, a przedsiębiorców do ich zatrudnienia.

Powstaje zatem pytanie, jakie sa przyczyny takiego zjawiska. W literaturze i w badaniach wymienia się szereg barier, które niejako tłumaczą ten stan rzeczy. Znajduja się one zarówno po stronie postaw pracodawców, jak i zachowań niepełnosprawnych.

Jednak głównych przyczyn należy upatrywać w systemie wsparcia dla podmiotów zatrudniających osoby niepełnosprawne. System ten ulega od wielu lat ciagłym zmianom, co powoduje niestabilność sytuacji finansowej tych podmiotów i nie zachęca do zwiększania zatrudnienia osób niepełnosprawnych.

$\mathrm{Na}$ taką ocenę mają wpływ m.in.:

- $\quad$ bardzo złożony system wspomagania;

- brak sprawnego monitorowania systemu;

- zróżnicowanie jakościowe i ilościowe przyznanej pomocy;

- zróżnicowanie podwyższonych kosztów ze względu na przyczyny niepełnosprawności;

- zróżnicowanie wysokości uzyskiwanych ulg refundacji [Barczyński, 2010]. 


\section{Literatura}

Barczyński A., 2010, Identyfikacja jakościowa i ilościowa kosztów zwiekeszenia aktywności zawodowej osób niepetnosprawnych, Politechnika Częstochowska, Częstochowa.

Frąckiewicz-Wronka A., Zrłek M., 2002, Rz̨eczywiste i pożqdane działania jednostek samorz̨adu terytorialnego na rzecz. osób niepetnosprawnych, [w:] Społeczne problemy osób niepetnosprawnych, Sikorska J. (red.), IFiS PAN, Warszawa.

GUS BAEL, www.niepelnosprawni.gov.pl.

Jaworski J., 2009, Praca dla osób niepetnosprawnych w zwalczaniu ich wykluczenia spotecznego. Ocena polskiego systemu wspierania zatrudnienia osób niepełnosprawnych, Opracowania PBZ, Warszawa.

Kietlińska K., 2010, Rola trzeciego sektora w spoteczeństwie obywatelskim, Difin, Warszawa.

Kowalczyk O., 1993, Rehabilitacja osób niepełnosprawnych - nowe rozwiqzania, ORPHA, Wrocław.

Koza A., 2015, Sytuacja na rynku pracy osób niepelnosprawnych i jej wplyw na gospodarke finansowa Państwowego Funduszu Rehabilitacji Osób Niepełnosprawnych, [w:] Problemy ekonomii, polityki ekonomicznej i finansowej, Sokołowski J. (red.), Prace Naukowe Uniwersytetu Ekonomicznego we Wrocławiu. Ekonomia, nr 401.

Kuźnicki W., Krupa P., 2000, Zaktady pracy chronionej i inni pracodawcy osób niepetnosprawnych od 1.01.2000, Kruk, Warszawa.

Majewski T., 2005, Jak organizowaí zatrudnienie wspomagane w sposób niepełnosprawnych?, „Praca i Rehabilitacja Niepełnosprawnych”, nr 10(902).

Malinowska-Misiąg E., Misiag W., 2006, Finanse publiczne w Polsce, Lexis Nexis, Rzeszów - Warszawa.

Mączyński G., 2002, Opodatkowanie zakładów pracy chronionej, Difin, Warszawa.

Narodowa Strategia Integracji Spotecznej dla Polityki Spolecznej, 2004, Warszawa.

Poliwczak I., 2007, Wyrównywanie sqans osób niepetnosprawnych na rynku pracy, Krajowa Izba Gospodarczo-Rehabilitacyjna, Warszawa.

Przybyłka A., 2001, Praca osób niepetnosprawnych, „Polityka Społeczna”, nr 4.

Rozporządzenie Ministerstwa Pracy i Polityki Społęcznej w sprawie miesięcznego dofinansowania wynagrodzeń pracowników niepełnosprawnych, Dz. U. nr 50 poz. 261 z $2011 \mathrm{r}$.

PFRON, Sprawozdania z realizacji planu rzeczowo-finansowego z działalności Państwowego Funduszu Rehabilitacji Osób Niepełnosprawnych za lata 20132016, https://bip.pfron.org.pl/pfron/budzet-funduszu/.

Szymanowska J., 2003, Zatrudnienie osób niepełnosprawnych w swietle obowiqzujacych przepisów, „Praktyka Społeczna”, nr 4.

Uchwała Sejmu RP z dnia 1 sierpnia 1997 r., Karta Prawa Osób Niepełnosprawnych, M.P. nr 50 poz. 475.

Ustawa z z dnia 27 kwietnia 2006 r. o spółdzielniach socjalnych, Dz. U. nr 94 poz. 651 z 2006.

Ustawa z z dnia 9 maja 1991 r. o zatrudnieniu i rehabilitacji zawodowej osób niepełnosprawnych, Dz. U. nr 46 poz. 201 z 1991 r. 
Ustawa z dnia 27 sierpnia 1997 r. o rehabilitacji zawodowej i społecznej oraz zatrudnieniu osób niepełnosprawnych, tekst jednolity, Dz. U. nr 123 poz. 776 z 1997 r. z późn. zm.

Zatrudnienie osób niepetnosprawnych. Informacje dla pracodawcón oraz dla osób zaktadajacych firme, PFRON, 2008. 